\title{
The Malaysian Homestay Program and the Japanese Minshuku: A comparative study
}

\author{
Rohaslinda Ramele ${ }^{1}$, Juichi Yamazaki ${ }^{2}$ \\ ${ }^{1}$ Sustainable Heritage Environment Research Group, Faculty of Architecture, Planning and Surveying, \\ Universiti Teknologi MARA Selangor, Malaysia. \\ ${ }^{2}$ Graduate School of Engineering, Kobe University, Japan. \\ rohaslinda@uitm.edu.my, yamazaki@kobe-u.ac.jp \\ $+60102285232$
}

\begin{abstract}
This paper discusses the characteristics of rural tourism in Malaysia and Japan by comparing the Malaysia Homestay Program and the minshuku. Japan has been chosen as a comparative case study since Japanese tourists are the second-highest number of foreign tourists visited the Malaysian Homestay Program until 2018. Findings have shown that the Malaysia Homestay Program was derived from the English bed-and-breakfast, while the minshuku has been influenced by the European farm-stay. Although they differ in concepts, organizations, regulations, and community participation, both have contributed to the development of the tourism sectors in both countries.
\end{abstract}

Keywords; Malaysia Homestay Program; minshuku; lifestyle experience; urban-rural interchange

eISSN: 2398-4287 @ 2020. The Authors. Published for AMER ABRA cE-Bs by e-International Publishing House, Ltd., UK. This is an open access article under the CC BYNC-ND license (http://creativecommons.org/licenses/by-nc-nd/4.0). Peer-review under responsibility of AMER (Association of Malaysian Environment-Behaviour Researchers), ABRA (Association of Behavioural Researchers on Asians) and cE-Bs (Centre for Environment-Behaviour Studies), Faculty of Architecture, Planning \& Surveying, Universiti Teknologi MARA, Malaysia. DOI: https://doi.org/10.21834/ebpj.v5iSI2.2525.

\subsection{Introduction}

An important part of the world tourism industry is rural tourism, which focuses on tourists who are looking for deeper experiences in the local lifestyle and culture than a typical tourist to the cities, beach resorts, and forests are looking for. In addition to economic contributions to the international and national tourism industries, rural tourism is also linked directly to the rural development policy. OECD (1994), Sharpley and Sharpley (1997), and Sharpley (2002) further clarified rural issues (falling employment and income levels, loss of public services, and consequential emigration of younger and better-educated community members) that has led policy planners and rural leaders to actively consider rural tourism as the solution to many rural issues due to local job creation, environmental protection, environmental enhancement, relatively low investment costs, a wider role for women, and closer urban-rural contact.

Sumarjan et al. (2014) divided the types of rural tourism into cultural tourism, natural tourism, village tourism, eco-tourism, agricultural tourism, and farmland, or farm-tourism. Rural tourism is further categorized as community-based tourism, where the rural communities participate and use local knowledge, and require fewer skills (especially for women) as waitresses, retail assistants, or accommodation personnel (Lee \& Thompson, 2006). Hatton (1999) identified rural tourism has contributed economically and influences a community; it is socially sustainable; respects local cultures, heritage, and traditions; and represents different environments, growth patterns, cultural values, and stages of development. Further, Hatton also described the impetus for the development, leadership, support from local and regional governments, cultural heritage, natural environment, employment opportunities, and the relationship between corporations and communities were all important themes to instigate community-based tourism. The characteristics of rural tourism in comparison to

eISSN: 2398-4287 @ 2020. The Authors. Published for AMER ABRA CE-Bs by e-International Publishing House, Ltd., UK. This is an open access article under the CC BYNC-ND license (http://creativecommons.org/licenses/by-nc-nd/4.0). Peer-review under responsibility of AMER (Association of Malaysian Environment-Behaviour Researchers), ABRA (Association of Behavioural Researchers on Asians) and cE-Bs (Centre for Environment-Behaviour Studies), Faculty of Architecture, Planning \& Surveying, Universiti Teknologi MARA, Malaysia.

DOI: https://doi.org/10.21834/ebpj.v5iSI2.2525. 
typical tourism are relaxing environments; open spaces; traditional village charms; outdoor activities; wildlife; beautiful natural scenery; and opportunities for direct participation by tourists in such activities as fruit picking and eating at local inns (Page \& Getz, 1997; Howie, 2003).

Nevertheless, rural tourism is defined differently in each country. Lane (1994) said that rural tourism is often functional, related to small-scale and traditional activities and enterprises, environmental aspects and heritage, non-uniform, and reflected the complexity of the rural environment. Rural tourism has been developing since the 1950s in European countries and has only been growing in Asian countries since the 1980s (Arahi, 1998). The concept, implication, development style, objectives, components, regulations, and participating organizations in rural tourism in Asia are also different from Europe as well as in each Asian country. Rural tourism in Asia has been developed by the rural community itself and concentrates on providing experiences with agriculture, fishery, forestry, and culture for tourists in contrast to the European model (Miyazaki, 2006). While in Europe, the families of the farmers themselves mostly managed the rural accommodations. In Asia, government organizations, local authorities, and the rural community manage rural accommodations and rural tourism programs. However, some concepts of rural tourism in Asia have been influenced by bed-andbreakfasts and farm stay, which were created and have been active in Europe for a long time.

Meanwhile, in Malaysia, the most important and the most successful rural tourism product is the Malaysia Homestay Program, which was established with the concept as a 'lifestyle experience' (MOTAC, 1995). Rural tourism in Japan, in comparison to Malaysia, is based on the concepts of the farming experience and lifestyle experience in a farm village and largely been influenced by the farm tourism model of European countries (The Organization for Urban-Rural Interchange Revitalization, 2013). Japan has introduced the minshuku (farm inn) as its most important rural tourism product. This study compared these two products of rural tourism in Malaysia in Japan to identify the similarity and differences, and characteristics of each product that have contributed to their success in the implementation. It is expected to benefit both countries on their implementation of rural tourism products to learn from each other's characteristics.

\subsection{Method}

This paper focuses on the implementation of the Malaysia Homestay Program and minshuku as the most important rural tourism products in both countries, respectively. The comparison of both products is discussed to show the differences for each concept, related government organizations, regulations, community participation, and identical characteristics influence on its development in each country, respectively. The methodology used in this study consists of qualitative methods where document reviews and content analysis on related government's official guidelines, official reports and research papers on both types of rural tourism, and interviews with the persons in charge with both products are carried out.

\subsection{Results and Discussion}

\subsection{Rural Tourism in Malaysia and Japan}

During the 1980s, the Malaysian government began to build Cultural Village Museums in villages due to an increasing number of tourists visiting rural areas (Ramele and Yamazaki, 2013). Finally, after realizing the potential of Malay Kampung (Malay Village) as a new rural tourism attraction, the Malaysian government established the Malaysia Homestay Program in rural villages to encourage rural Malays to become actively involved in the tourism sector.

In the Rural Tourism Master Plan (RTMP), which was prepared by the Ministry of Tourism, Arts and Culture Malaysia (MOTAC) in 2001, rural tourism was defined as 'tourism that provides opportunities for visitors to visit rural attractions, and to experience the culture and heritage of Malaysia, thereby providing socio-economic benefits for local communities including day-visits'. Rural tourism in Malaysia includes recreational tourism and agro-tourism (tourism as an agricultural enterprise). However, it is differentiated from eco-tourism and marine tourism because they are located in remote areas and regulated under separate national plans. The target customers are known as 'middle ground tourists' because they occupy the middle ground between mass tourism and ecotourism as well as preferring rural areas between cities or resorts and remote areas.

Rural tourism in Malaysia offers activities such as scenic touring, visiting cultural and heritage-related attractions, resting and relaxing surrounded by nature, enjoying nature and related activities (walking, cycling, and fishing), river trips, wildlife-watching, experiencing traditional lifestyles, attending local festivals and traditional entertainment, buying traditional crafts and local specialties, and eating typical food. The types of accommodation provided in the rural areas are small hotels, lodges, chalets, bed-and-breakfast, guesthouses, homestays, longhouses in Sabah and Sarawak (Borneo Island), nature camps or campsites, and kampung stay (a house built in traditional Malaysian architecture in rural areas with basic facilities and focused on long-stay tourists). Currently, the Malaysian government is actively promoting homestays as the most important product of rural tourism by providing educational and financial support through the Malaysia Homestay Program.

In contrast to Malaysia, rural issues in Japan are caused by migrations to urban areas until the 1970s due to farm crisis, lack of nonfarm jobs, and poor services and education (Kitano, 2009). Rural development strategies were carried out to solve rural depopulation, including rural industrialization and rural tourism. Resort development boomed in rural Japan in the late 1980s, mainly to provide people in urban areas with a natural environment to relax and rejuvenate in (Furukawa, 2007). The Comprehensive Resort Area Development Law was enacted in 1987 and a local 'resort plan' was formulated for each prefecture to develop depopulated areas with new tourism strategies. This was followed by the elimination of forest reserves, revisions to the National Park Law, and construction of ski resorts, golf courses, and marine sports facilities in rural areas. However, when the 'bubble economy' collapsed in the early 1990s, large-scale 
resort projects disappeared and new projects began at smaller-scale, such as family resorts and rural resorts in farms and mountain villages.

Rural tourism (called green tourism for farms and mountain villages; and blue tourism for fishing villages) officially began in 1992 and is also known as urban-rural interchange (Miyazaki, 2006). Rural tourism has been developed in Japan for three purposes: 1. to revitalize agriculture, forestry, fishery, farm villages, mountain villages, and fishing; 2. to preserve nature, landscapes, and traditional cultures; and 3. to promote rural lifestyles to urban people. In the fifth Comprehensive National Development Plan (CNDP), which was carried out in 1998, rural tourism is defined as 'spending leisure time in rural communities'. Rural tourism consists of all tourism in rural areas and is based on farm-visits and farm-stays (also called farm tourism, leisure agriculture, or agro tourism) is further categorized into agricultural tourism.

Tourism activities provided in rural Japan are nature observation, bird watching, basking in the woods, skiing or snowboarding, canoeing or rafting, cultivating rice, harvesting fruit or vegetables, potato digging, planting young trees, picking edible wild plants, picking mushrooms, making charcoal, fishing, seining, and cooking local specialty dishes. Accommodations for tourists in rural areas mostly consist of minshuku.

\subsection{The Malaysian Homestay Program and Minshuku}

During the popularity of rural tourism in Malaysia in the 1980s, the Malaysian Homestay Association was established to manage accommodations for Japanese youths on an exchange or field program to rural areas (Hamzah, 2008). In the same period, the Ministry of Agriculture used homestays as accommodations to promote the agro-tourism industry. After realizing the potential of Malay Kampung as a tourism product, the MOTAC carried out a pilot project known as Desa Murni Homestay in five selected villages in Pahang in 1988. The MOTAC established the Malaysia Homestay Program officially in 1995 in all villages in rural areas of Malaysia, because of the success, increasing number of tourists, and income earned from the Desa Murni Homestay project. This program is derived from the bed-and-breakfast concept, which has existed in European countries for a long time. In this program, tourists stay with villagers (host families) for one or more days and participate in the program activities provided by the homestay committee.

The Malaysian Homestay Program is established at the national level by the MOTAC and charges a homestay program registration, provides communal facilities for homestay program activities, and promotes all homestay programs at the national and international levels. The Ministry of Rural and Regional Development (provides free training for host families, improves public facilities, and infrastructures in participating villages), the Ministry of Education (promotes homestay programs at domestic and foreign schools), the Ministry of Agriculture (priorities agricultural development in participating villages), and the Malaysia Homestay Association and Ministry of Health (carry out health and hygiene inspections at host family homes) are also involved. Participants also include private and NGO organizations such as travel agencies as well as the Village Development and Safety Committee in each participating village.

The participation concept is volunteerism. The MOTAC has carried out the Malaysia Homestay Registration Guidelines to be followed by participating villages and villagers before and after the establishment of their homestay programs to ensure the quality of the program as a national rural tourism product. Each homestay program may consist of one or more villages. However, there have to be 10 or more host families to participate in. Besides, the village to be accessible, clean, and safe, the community in the village has to 'act and think tourism' and allow their homes to be periodically inspected by related ministries. They also have to attend Homestay Basic Training and language courses provided by the Ministry of Rural and Regional Development to provide the basic knowledge and skills for tourism and management.

The Malaysian Homestay Program involves families and communities of the village, including existing committees. Villagers create a homestay committee to manage tourist reception, program activities, and interaction between participating villagers and related ministries. Villagers participate in this program as homestay committee members (usually led by the village headman), host families, traditional martial art, dance, games, and musical performers (existing youth committee members), cooks or caterers (existing woman committee members), drivers, and farm guides. The income earned from this program will be received by the committee and later divided to host families, performers, drivers, and guides according to the number of rooms provided to tourists and involvement during program activities.

Except for the 'free and easy' package, most tourists are participating in fixed-schedule program activities, which can be altered upon request. The homestay committee members create these activities for their homestay program themselves based on their daily activities, economic activities, communal activities, and customs and traditions. Among these activities are eating local cuisine at the host family's house, watching and experiencing traditional martial arts, dances, games, musical performances, attending wedding ceremonies, religious festivals, gatherings, fishing, watching and experiencing agricultural activities (paddy harvesting, rubber tapping, oil palm plucking, and coconut plucking), sightseeing, visiting nearby tourists attractions, jungle tracking, and water rafting. The Malaysian Homestay Program has also involved with the 'Plant a Tree Program', where each tourist is encouraged to plant a fruit tree in the village they have visited. In addition to the environmental preservation and landscape beautification, it also encourages tourists to revisit the village to see the progress of the tree they planted.

Program activities provided by each homestay program differ according to the multi-ethnicities of Malays in each state, district, and village (Ramele \& Yamazaki, 2013). This is due to the migration of Javanese, Bugis, and Minangkabau ethnic groups from Indonesia to Peninsular Malaysia before independence. There are more than 50 aborigine ethnicities on Borneo Island alone. Each Malay Kampung has its own local culture, lifestyle, custom, and cuisine by following their original ethnicity. These characteristics attract foreign tourists and domestic tourists among Malays, Chinese, and Indians from other states, districts, and villages. By March 2018, there were 209 homestay programs established in 357 villages throughout Malaysia, and 4,025 families participated as host families and 5,650 rooms were provided for tourists. 
Meanwhile, in Japan, it is women who first began the day-to-day running of the tourism business in rural areas by selling agricultural products directly from farms and operating food-processing factories to increase their incomes (Arahi, 1995). The minshuku concept in Japan has been influenced by farm tourism from European countries, which also aims for long-stay tourists from urban areas (Miyazaki, 2006). Tourists do not stay in the villagers' homes (host families' homes), but in the minshuku, which is managed by the farmers. The minshuku can be in various styles, such as detached, inside the main house, for children, for large groups, for general use, a campsite, or a luxurious room (Arahi, 1998). Farmers do not need to serve expensive traditional meals as other commercial inns do this, but they need to provide rooms to sleep in and simple meals.

Groups of government organizations (association of agriculture, forestry, and fisheries), local authorities, associations of village and farmers, and organizations established by the community itself manage the minshuku at national, regional, and community levels. At the national level, the minshuku is managed with some funding and operated by the Ministry of Agriculture, Forestry, and Fisheries and The Organization for the Revitalization of Urban-Rural Interchange. The management of the minshuku is divided into four styles (Arahi, 1998): 1. privately funded and privately managed; 2 . publicly funded and publicly managed; 3 . publicly funded and privately operated, and; 4. jointly funded and operated. The second and third types of management are funded by public organizations or and agricultural cooperatives. The last type of management is where cities and rural villages jointly fund and operate the minshuku based on a membership system. The income of the minshuku will be given directly to the farmers or the organization or divided by following the type of management used.

Several regulations have been enacted for villagers to establish a minshuku and permit the site (which has to be more than $33 \mathrm{~m}^{2}$ ), accessibility, type of buildings, meals, and other equipment that need to be applied from local authorities, Public of Health Centres, and Fire Departments (Arahi, 1998). Furthermore, these regulations are further detailed for each prefecture and each prefecture enacts their own 'Minshuku Opening Guidance'. The terms needed for each farm, mountain, and fishing villages are different as well as the management and operation styles. They can operate all year, seasonally, or weekends and public holidays (Nagano Prefecture, 2007). In contrast to community participation in the Malaysia Homestay Program, minshuku rarely involves the whole community or existing committee in the village during tourist stays. Most of the minshuku are managed and operated by individual farming women or the elderly.

According to the types of minshuku, some do not provide any activities for tourists and some provide private land for farming and kitchen space in the house where tourists can plant their vegetables and fruits, and cook their meals, respectively. Nevertheless, while staying at the minshuku, tourists can interact with local people, attend local festivals, participate in communal activities, visit temples and shrines, learning regional cooking, and listen to old tales in the village. Moreover, these activities change seasonally and contribute to different characteristics of rural tourism in Japan. By early 2018, the Ministry of Agriculture, Forestry, and Fisheries of Japan recorded that the number of minshukus built in the country to have reached 2,030; 1,860 managed by individuals, 60 managed by cooperation bodies, and 110 managed by organizations. Table 1 describes the comparison of the Malaysian Homestay Program in Malaysia and the minshuku in Japan based on previous statements

Table 1: The Comparison of the Malaysian Homestay Program and the Japanese Minshuku

\begin{tabular}{|c|c|c|}
\hline & Malaysian Homestay Program & Minshuku \\
\hline Reference & English bed and breakfast & European farm tourism \\
\hline Concept & Lifestyle experience & $\begin{array}{l}\text { Farming experience/lifestyle } \\
\text { experience in a farm village }\end{array}$ \\
\hline Definition & $\begin{array}{l}\text { Tourist lives with a host family who } \\
\text { lives in the rural villages, experience } \\
\text { the family's daily lifestyle, and } \\
\text { participate in the village's economic, } \\
\text { community, and cultural activities }\end{array}$ & $\begin{array}{l}\text { Tourist stays in a private farmhouse or } \\
\text { an inn built on a farm in traditional } \\
\text { Japanese style that is managed by } \\
\text { families engaged in agriculture, } \\
\text { forestry, or fishery }\end{array}$ \\
\hline Objective & $\begin{array}{l}\text { To provide Malay Kampungs as a } \\
\text { new tourism product; to encourage } \\
\text { rural Malays to participate in the } \\
\text { tourism sector }\end{array}$ & $\begin{array}{l}\text { To revitalize rural area; to preserve the } \\
\text { landscape and traditional culture; to } \\
\text { promote a rural lifestyle to urban } \\
\text { people }\end{array}$ \\
\hline $\begin{array}{l}\text { Government } \\
\text { organization } \\
\text { involved }\end{array}$ & National level & $\begin{array}{l}\text { National, regional, and community } \\
\text { levels }\end{array}$ \\
\hline Regulation & $\begin{array}{l}\text { Malaysian Homestay } \\
\text { Registration Guidelines }\end{array}$ & Minshuku Opening Guidance \\
\hline Management & $\begin{array}{l}\text { Homestay committee / homestay } \\
\text { cooperative / regional } \\
\text { government }\end{array}$ & $\begin{array}{l}\text { Privately funded, privately } \\
\text { managed / publicly funded, } \\
\text { publicly managed / publicly } \\
\text { funded, privately operated / jointly } \\
\text { funded and operated }\end{array}$ \\
\hline $\begin{array}{l}\text { Villager } \\
\text { participation }\end{array}$ & $\begin{array}{l}\text { Homestay committee members; } \\
\text { host family; cultural show } \\
\text { performer; cook; driver; SME } \\
\text { and farm owner; guide }\end{array}$ & Minshuku owner \\
\hline
\end{tabular}




\begin{tabular}{|c|c|c|}
\hline Accommodation & $\begin{array}{l}\text { Tourist room in the host family } \\
\text { house (Malay House) }\end{array}$ & $\begin{array}{l}\text { Private farmhouse (detached / } \\
\text { inside the main house / for } \\
\text { children / for large group / } \\
\text { campsite / luxurious room }\end{array}$ \\
\hline Meal & $\begin{array}{l}\text { Breakfast and dinner with the } \\
\text { host family }\end{array}$ & Simple meal / self-cooked \\
\hline Activity & $\begin{array}{l}\text { Fixed schedule created by the } \\
\text { homestay committee }\end{array}$ & $\begin{array}{l}\text { Some are provided with private } \\
\text { land for farming and kitchen }\end{array}$ \\
\hline Characteristics & $\begin{array}{l}\text { Multi-ethnicities of Malays in } \\
\text { each state, district, and village }\end{array}$ & $\begin{array}{l}\text { Village activities change due to } \\
\text { four seasons }\end{array}$ \\
\hline
\end{tabular}

\subsection{The Relationship of Malaysia and Japan}

The relationship between Malaysia and Japan is clarified, where Japan was listed first place in the top 10 participating countries in Malaysia My Second Home (MM2H) program in 2012 (MOTAC, 2012). In recent years, Malaysia has been chosen as a destination for long-stay tourists especially from Japan. Moreover, as described in Table 2, Japanese tourists are also recorded as the second-highest number of foreign tourists who visited the Malaysian Homestay Program between January and March 2018 (MOTAC, 2018). This number is mainly contributed by groups of students from Japanese schools and universities, and some are visiting the school student exchange programs.

Japanese youths continued to be the main tourists visiting Malay Kampungs after the Malaysian Homestay Program was established by the MOTAC in 1995. According to Hamzah (2008), Desa Murni Homestay in Pahang, Banghuris Homestay in Selangor, Relau Homestay in Kedah, and Pelegong Homestay in Negeri Sembilan are among successful homestay programs that are mainly visited by the Japanese youths under the student exchange programs $(95 \%, 72 \%, 58 \%$, and $42 \%$, respectively). Moreover, $80 \%$ of Japanese youths have repeatedly visited the Desa Murni Homestay, which has the strongest business connections with Japan through the student exchange programs. In this program, the Malaysian Homestay Association held the marketing and promotion of the homestays in Japan, which has brought more than 50,000 Japanese youths from schools in Japan to the homestays.

Table 2: Number of Foreign Tourists According to Countries (January-March 2018)

\begin{tabular}{lll}
\hline Countries & Number of Tourists & Percentages \\
\hline South Korea & 10,272 & $48.5 \%$ \\
Japan & 2,890 & $13.7 \%$ \\
Singapore & 2,696 & $12.7 \%$ \\
Europe & 1,765 & $8.3 \%$ \\
China & 1,691 & $8.0 \%$ \\
Australia & 488 & $2.3 \%$ \\
USA & 352 & $1.7 \%$ \\
Canada & 340 & $1.6 \%$ \\
Indonesia & 195 & $0.9 \%$ \\
Others & 476 & $2.2 \%$ \\
\hline
\end{tabular}

Source: (MOTAC, 2018)

\subsection{Conclusion}

The establishment of rural tourism in Malaysia and Japan was carried out during the late 1980s; however, there are slightly different objectives between them. In Malaysia, rural tourism is aimed to promote the culture and heritage of rural Malaysia (mainly Malay Kampung) and to enhance the economic status of rural people (mainly Malays). In Japan, rural tourism, which is also called green tourism, is promoted to encourage an interchange between urban and rural people as well as to create rural revitalization and naturalcultural preservation. Although the Malaysia Homestay Program and the minshuku are both derived from and influenced by rural tourism from European countries, they have been constructed with different concepts, related organizations, regulations, community participation, and other characteristics. Nevertheless, the identical characteristics have contributed to success factors for the homestay program and the minshuku as well as have benefited the tourism sector and rural development.

\section{Acknowledgment}

The authors would like to acknowledge the Ministry of Tourism Malaysia for providing statistics for this research paper and the LESTARI Research Fund (600-RMI/DANA 5/3/LESTARI (0164/2016)) from Universiti Teknologi MARA, Malaysia for a part of the data collection activities. 


\section{References}

Arahi, Y. (1995). Perspectives and Characteristics of Group Processing Activities by Rural Women, Rural Life Society and Japan, 8, 47-58.

Arahi, Y. (1998). Rural Tourism in Japan: The Regeneration of Rural Communities, Taipei: Food and Fertilizer Technology Centre.

Davison, R. (1998). Travel and Tourism in Europe (2nd ed.), Harlow: Longman.

Furukawa, A. (2007). Village Life in Modern Japan. (K. Onoda, Trans.), Melbourne: Trans Pacific Press.

Howie, F. (2003). Managing the Tourist Destination, London: Cengage Learning EMEA.

Hamzah, A. (2008). This is a chapter in J. Cochrane (Ed.), Asian Tourism: Growth and Change (pp. 193-207), Oxford: Elsevier.

Kitano, S. (2009). Space, Planning, and Rurality: Uneven Rural Development in Japan, Canada: Trafford Publishing.

Lane, B. (1994). What is Rural Tourism, Journal of Sustainable Tourism, 2, 7-21, doi: 10.1080/09669589409510680

MOTAC (1995). Malaysia Homestay Registration Guidelines, Putrajaya: Ministry of Tourism, Arts and Culture Malaysia.

MOTAC (2001). Rural Tourism Master Plan (The Main Report: Volume 1), Putrajaya: Ministry of Tourism, Arts and Culture Malaysia.

Miyazaki, T. (2006). Agriculture, Farm Village and Green Tourism at Japan and Asia. Kyoto: Showado.

MAFF (2018). 2018 World Census of Agriculture and Forestry in Japan, Tokyo. Ministry of Agriculture, Forestry and Fisheries.

MOTAC (2013). Homestay Program Statistic Report March 2018. Putrajaya: Ministry of Tourism, Arts and Culture Malaysia.

MOTAC (2012). Malaysia My Second Home Program Performance from 2002-2012.

Nagano Prefectural (2007). Minshuku Opening Guidance. Nagano: Nagano Prefectural.

OECD (1994). Tourism Policy and International Tourism in OECD Countries 1991-1992, Paris: Organization for Economic Co-operation and Development.

Page, S. J. and Getz, D. (1997). The Business of Rural Tourism: International Perspectives, London: Cengage Learning EMEA.

Ramele, R. B. and Yamazaki, J. (2013). A Study on Traditional Javanese-Malay Kampung Structure, Culture and Community Activities in Kampung Sungai Haji Dorani, Selangor, Malaysia. Paper presented at the meeting of The Asian Conference on Asian Studies 2013, Osaka.

Ramele, R. B. and Yamazaki, J. (2013). Homestay Program, a New Trend in Malaysian Rural and Regional Development, Paper presented at the meeting of the 12th International Congress of Asian Planning Schools Association, Taipei.

Sharpley, R. and Sharpley, J. (1997). Rural Tourism: an Introduction, Boston: International Thompson Business.

Sharpley, R. (2002). Rural Tourism and Challenge of Tourism Diversification: The Case of Cyprus, Tourism Management, 23, 233-244. doi:10.1016/S02615177(01)00078-4

Sumarjan, N., Zahari, M. S. M., Radzi, S. M., Mohi, Z., Hanafiah, M. H. M., Bakhtiar, M. F. S., Zainal, A. (Eds.) (2014). Hospitality and Tourism: Synergizing Creativity and Innovation in Research, London: Taylor \& Francis Group.

The Organization for Urban-Rural Interchange Revitalization (2013). Journey to the Countryside and Nature of Japan: Green Tourism, Retrieved from The Organization for Urban-Rural Interchange Revitalization website: http://www.kouryu.or.jp/service/a51k290000000ccg-att/english.pdf 